\title{
Austronea patersoniae (Asparagaceae, Scilloideae), a new species from the Eastern Cape Province in South Africa
}

\author{
MARIO MARTÍNEZ-AZORÍN ${ }^{*}$, ANTHONY P. DOLD ${ }^{2} \&$ MANUEL B. CRESPO' \\ ${ }^{\prime}$ Depto. de Ciencias Ambientales y Recursos Naturales (dCARN), Universidad de Alicante, P. O. Box 99, E-03080 Alicante, Spain; \\ e-mail:mmartinez@ua.es \\ 2Selmar Schonland Herbarium, Department of Botany, Rhodes University, Grahamstown 6140, South Africa. \\ "author for correspondence
}

\begin{abstract}
Our fieldwork in the Eastern Cape province of South Africa revealed an undescribed species of Austronea which was named by Schonland as "Urginea Patersoniae Schonl. Ms.", but never validly published. We here describe Austronea patersoniae to include plants showing bulbs with loose scales; 5-9 narrowly linear erect leaves with papillate margins; elongate peduncle; lowermost bracts with a broad, flat, papery spur and reddish flowers with papillate filaments. We provide a complete morphological description as well as data on ecology and distribution.
\end{abstract}

Keywords: Distribution, ecology, Hyacinthaceae, taxonomy, Urgineoideae

\section{Introduction}

Austronea Mart.-Azorín, M.B.Crespo, M.Pinter \& Wetschnig in Martínez-Azorín et al. (2018a: 105) has been recently described to include some species of Hyacinthaceae subfamily Urgineoideae (= Asparagaceae subfam. Scilloideae tribe Urgineeae) from southern Africa, which were traditionally included in Urginea Steinheil (1834: 321) or Drimia Jacq. ex Willdenow (1799: 165) sensu lato and resemble those of Fusifilum Rafinesque (1837: 27). However, species of Austronea show a unique syndrome of morphological characters, such as the leaves usually leathery and thickened; the subcorymbose or congested raceme commonly nodding at early developmental stages, the reddish to greenishyellow tepals (see flower buds), which are usually connate at the base to form a distinct cup and patent free lobes, the filaments linear to ovate-lanceolate (not distinctly fusiform), smooth or papillate below, the ovary green to yelloworange, and the seeds commonly trigonous in outline, tetrahedrally folded and narrowly winged along the angles (see Martínez-Azorín et al. 2018a). This genus is also supported by our phylogenetic studies (see Fig. 3 in Martínez-Azorín et al. 2018b) in which Austronea forms a strongly supported clade which is sister to Fusifilum.

Recent fieldwork in the Eastern Cape province of South Africa has resulted in the re-discovery of an undescribed species of Austronea that was first collected by T.V. Paterson in 1911 at Redhouse near Port Elizabeth, and later collected by several botanists from the same area. This species was included by Schonland (1919) in his flora of Uitenhage and Port Elizabeth as "Urginea Patersoniae Schonl. Ms.", but this name has never been validly published. He cites two collections by Drège, both numbered 3122, one from Port Elizabeth (not seen by us, perhaps an error) and another from Aloes (collected in November 1912, in GRA). He also cites two collections from Redhouse by T.V. Paterson (Paterson 2175) in October and November under the same collecting number. GRA has two Paterson specimens, both numbered 2175 and both from Redhouse, but collected in October 1911 and November 1914. Unlike Schonland we treat these as two unique specimens. This species was later included in the book "Wildflowers of the Port Elizabeth Area: Swartkops to Sundays Rivers" by Vanderplank (1998: 28) as "Drimia sp." and illustrated in Plate 9(4) of the same work. Vanderplank (1998) mentions that "Each small leaf springs from a small bulb, these have the appearance of an Haworthia plant. When the leaves die down, a short inflorescence appears with a red peduncle and flower stalks." This is in agreement with the comments annotated on the voucher Drège 3122 from Aloes, mentioning the "bulb scales fleshy, whitish, very loose, spoonshaped, distinctly petiolate" and "Urginea patersoniae Schonl. n. 
sp.”. This same collection was later identified as Drimia chalumnensis Dold \& Brink (2004: 631) by U. MüllerDoblies \& D. Müller-Doblies (Determinavit 02/05/2012). Manning \& Goldblatt (2018) followed this and included the collections Drège 3122 [as 2122] (PRE) and Cruden 300 (PRE) in Drimia chalumensis, mentioning that those collections from Port Elizabeth only differ from typical plants in the "taller inflorescences, $60-110 \mathrm{~mm}$ long, with slightly longer pedicels 4-6 mm long" and state that further fieldwork is necessary to assess the circumscription of the species and the status of the Port Elizabeth populations.

Our studies on living specimens from the wild and in cultivation provide evidence that the plants from Port Elizabeth area not only differ in the longer peduncle and pedicels, but also in the longer, erect, subterete leaves lacking thickened margins; the lowemost bracts with broad, flat papery spur and larger flowers, among other characters (see Martínez-Azorín et al. 2018a: 104; Fig. 3C), as shown below. Based on a distinct syndrome of morphological characters, we here describe Austronea patersoniae including a complete description and illustration as well as data on ecology and distribution.

\section{Materials and methods}

Detailed morphological studies were undertaken on cultivated and wild specimens following the terminology used for species of Hyacinthaceae in Martínez-Azorín et al. (2007, 2009). Herbarium specimens from the herbaria ABH, B, BLFU, BOL, GZU, GRA, K, M, MO, NBG, NU, NY, P, PRE, S, TCD, UPS, W, WU, Z, ZSS and ZT (acronyms according to Thiers 2019+) were studied. Authors of the cited taxa follow IPNI (2019+). Orthography of geographical names and grid-number system follow Leistner \& Morris (1976). Measurements of tepals, stamens and ovaries were made from fresh material.

\section{Description of new species}

Austronea patersoniae Mart.-Azorín, A.P.Dold \& M.B.Crespo, sp. nov. (Fig. 1)

$=$ Urginea patersoniae Schonland nom. nud.

Ab Austronea chalumnensis affinis bulbi habito et staminum filamentis papillatis, sed hac multo diversa nempe foliis erectioribus longioribusque ca. 30-45 mm (nec ad solum appressis et 15-30 mm long), pedunculo inflorescentiae multo longioribus ca. 8-15 cm long (nec usque ad $19 \mathrm{~mm}$ long), pedicellis longioribus 4-7 $\mathrm{mm}$ (nec 3-4 mm long), bracteis inferioribus applanato papyraceoque calcari munitis (non calcari minuto cornuatoque), perianthii lobis longioribus ca. 3.5-4.7 (nec 3.0-3.4 mm long), et seminibus majoribus ca. 2.6-3.4 mm (nec 1.6-1.9 mm long).

Type:-SOUTH AFRICA. Eastern Cape. Grahamstown (3326): Alicedale (-AC), 1 July 1919 (in flower and fruit), F. Cruden 300 (holotype GRA, isotype PRE)

Herbaceous deciduous geophyte. Bulb hypogeal, ovoid, 10-25 × 8-20 mm, usually proliferous and clump forming, composed of loose, white, thickened, pedunculate scales, with white membranous outer tunics. Roots fleshy, white, branched, $8-50 \times 0.6-1 \mathrm{~mm}$. Leaves 5-9, usually proteranthous and mostly withered at flowering time in wild plants, or sometimes synanthous in cultivation, aerial portion $30-45 \times 1.2-1.8 \mathrm{~mm}$, erect, narrowly linear with slightly incurved apex, fleshy-succulent, subterete to slightly flattened and canaliculated, rounded abaxially, dull dark green, with minute, cone-shaped, uniform in size, neatly organized papillae along the margins in the upper half of the leaf, rarely also papillate on the blade, with a white hypogeal leaf portion of ca. $30 \mathrm{~mm}$ long conecting to the bulb scales. Inflorescence nodding in bud, raceme 2-5 mm long, capitate or subglobose, with 7-20 flowers; peduncle at anthesis 8-15 cm long, purple in lower half, becoming green in upper half, erect or flexuose, glabrous, smooth; pedicels 4-7 $\mathrm{mm}$ long at anthesis, up to $10 \mathrm{~mm}$ in fruit, suberect to spreading, smooth; bracts ovate-lanceolate, $0.8-1.0 \mathrm{~mm}$ long, clasping the pedicels, spurred, the lowermost with a broad, flat, papery spur of ca. $1.5 \mathrm{~mm}$ long, white with a central darker band. Flowers pentacyclic, trimerous, stellate, opening about noon and withering in the evening, 1-3 flowers open at a time, flower buds reddish; tepals 6 , entire, reddish ('burnt orange'), with a darker longitudinal central band on the abaxial side, slightly glandulous at the apex, biseriate, outer overlapping inner at the base, connate at the base for ca. $1.5 \mathrm{~mm}$ to form a distinct cup, free portions patent to slightly reflexed; outer tepals ovate, 3.5-4.5 × 1.2-1.4 $\mathrm{mm}$; inner tepals ovate-lanceolate, $3.8-4.7 \times 1.3-1.4 \mathrm{~mm}$, both inner and outer with margins somewhat revolute at 


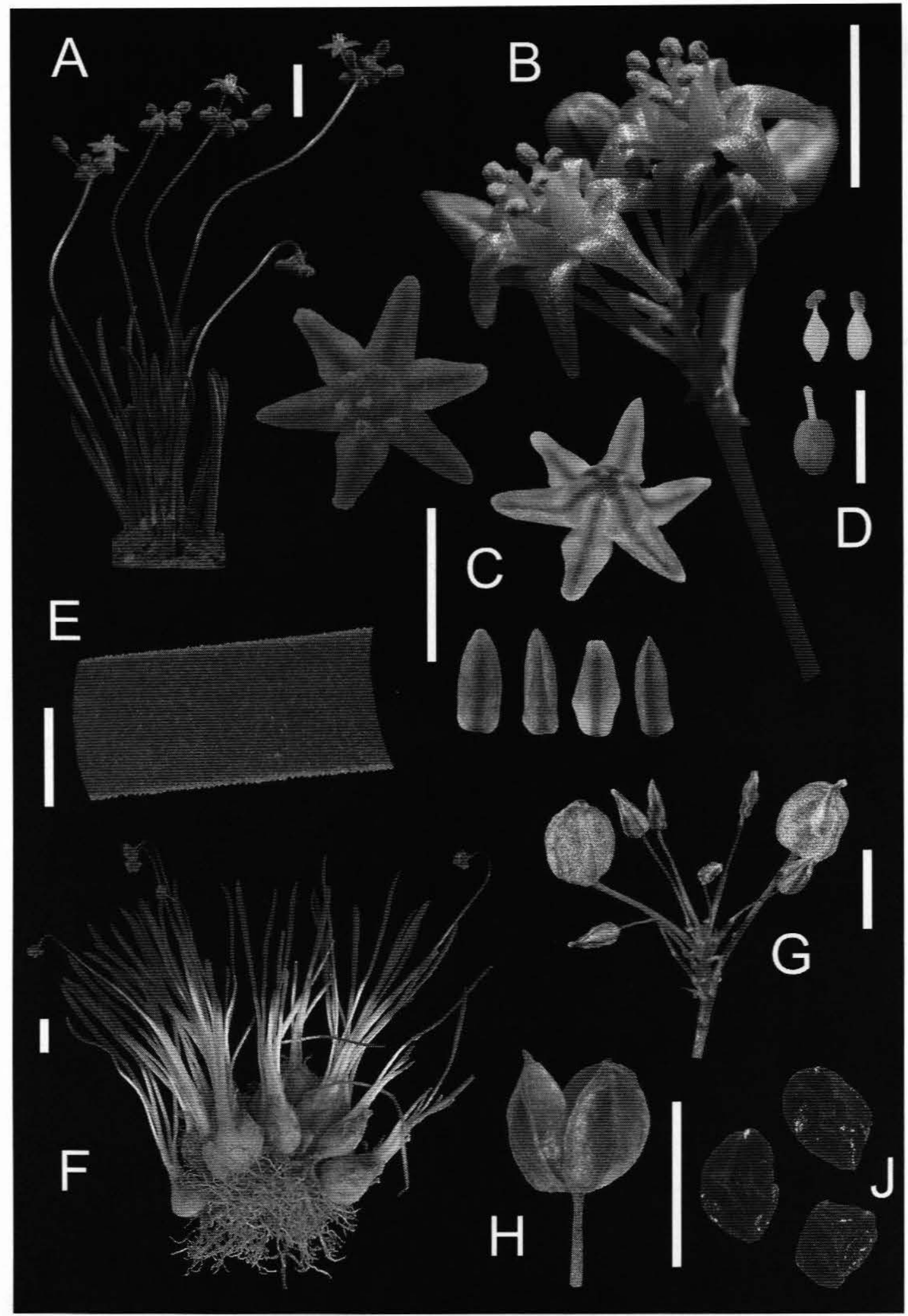

FIGURE 1. Austronea patersoniae Mart.-Azorín, A.P.Dold \& M.B.Crespo from Huguenot Farm, Barkly Bridge area, Addo, Eastern Cape, South Africa corresponding to Dold 16040 ex hort in flower on 13 October 2018 and in fruit on 20 November 2018. A. General habit showing erect leaves, flexuose peduncles and nodding young inflorescence; B. Detail of inflorescence with flowers showing papillate filaments; C. Flowers in frontal and dorsal views and dissected tepals; D. Stamens and gynoecium; E. Section of leaf showing papillae; F. Habit of a clump of plants in habitat with loose bulb scales; G. Infructescence; H. Dehisced capsule; J. Seeds. Scale bars: A, F: 1 cm; B-C, G-J: $5 \mathrm{~mm}$; D: $3 \mathrm{~mm}$; E: $1 \mathrm{~mm}$. 
anthesis. Stamens 6, suberect or slightly spreading, adnate to perigone for ca. $0.7 \mathrm{~mm}$; filaments white, fleshy, ovate with attenuate apex, flat, $1.3-1.8 \times 0.7-0.9 \mathrm{~mm}$, papillate; anthers yellow, oblong, ca. $0.7 \mathrm{~mm}$ long before dehiscence, dehiscing by longitudinal slits, with yellow pollen. Ovary green, ovoid, truncate to the style, $1.6-1.8 \times 1.2 \mathrm{~mm}$; style white, columnar, erect, ca. $1.1 \mathrm{~mm}$ long, trigonous in transverse section; stigma small, glandulose and slightly papillate. Capsule ovoid-globose, loculicidal, 4-5 $\times 3-4 \mathrm{~mm}$, valves splitting to the base, with the withered perigone segments circumscissile below and forming an apical cap. Seeds ca. 7 per capsule, black, glossy, 2.6-3.4 × 1.8-3.0 $\mathrm{mm}$, commonly trigonous or subellipsoidal in outline, tetrahedrally folded and narrowly winged along the angles, testa loose and easily detachable from the embryo, with colliculate testa cell walls.

Eponymy:-Named after Mrs. T.V. Paterson (née Florence Mary Hallack) (1869-1936) from Redhouse, who "indefatigably laboured in the exploration not only of the divisions of Uitenhage and Port Elizabeth, but also of other parts of South Africa which she has visited" (Schonland 1919; Glen \& Germishuizen 2010).

Phenology:-Austronea patersoniae flowers around September to October in the wild; fruits appear in November to December. Flowers short-lived, opening about midday and withering by dusk.

Habitat:- This species occurs in open patches between bush clumps, in fine sandy soil (called 'snotsand' in Afrikaans by local farmers), clay or limestone, in the Albany Thicket biome (Mucina \& Rutherford 2006).

Distribution:-Austronea patersoniae is only known from the surroundings of Jeffreys Bay, Port Elizabeth, Addo and Alicedale in the Eastern Cape Province of South Africa.

Diagnostic characters and taxonomic relationships:-Austronea patersoniae is easily identified by the clumpforming bulb with loose scales; the 5-9, narrowly linear, subtetere to slightly flattened and canaliculated, erect leaves with papillate margins; the elongate peduncle; the lowermost bracts, which each have a broad, flat, papery spur and the reddish flowers with papillate filaments. All studied populations show leaves with papillae only along the margins, but the collection Brown 99/11/24/PB/215 (GRA) from Jeffreys Bay also bears papillae on the blade of the leaf and the label indicates that they are "rough to the touch". However, it possesses the other diagnostic characters of $A$. patersoniae and we provisionally consider this as intraspecific variation.

Austronea patersoniae shows similar bulb structure and papillate filaments to A. chalumnensis, but the latter species differs in the smaller (15-30 mm long), blue-grey, flattened leaves that are leathery coriaceous, spreading and appressed to the ground with distinctly whitish, thickened and hardened margins covered by rounded, larger papillae which are clumped together along their whole length; the much shorter (up to $19 \mathrm{~mm}$ long) and permanently erect peduncle (probably due to its very short length), shorter pedicels (3-4 mm long), shorter and horn-like spur of bracts, and smaller tepals (3.0-3.4 mm long) and seeds (1.6-1.9 mm long) (see Martínez-Azorín et al. 2018a: 104; Fig. 3C). Austronea chalumnensis was described from two localities near the Chalumna River in the Eastern Cape Province. A third disjunct population was recently found on the farm Kariegasfontein, ca. $40 \mathrm{~km}$ west of Aberdeen (P. McNaughton s.n. GRA!) and matches the type well.

Austronea virens Schlechter (1897: 433) Martínez-Azorín et al. (2018a: 108) shares with A. patersoniae the erect, narrowly linear leaves, but the former differs by the compact bulb scales, the smooth filaments, and different distribution (western areas of the Western Cape Province of South Africa).

Additional material studied (paratypes):-SOUTH AFRICA. Eastern Cape: Humansdorp (3424): Jeffreys Bay, Aston Bay, north of Marina Martinique (-BB), elev. 20 m, coastal bush with fynbos patches, sandy soil on limestone bed, 24 November 1999 (in flower), P. Brown 99/11/24/PB/215 (GRA!); Port Elizabeth (3325): Addo, Barkly Bridge area, Huguenot Farm (-DA), open sandy patch between bush clumps in Sundays Thicket on bank of Sundays River, elev. 26 m, 5 October 2018 (in bud), A.P. Dold 16040 (GRA!); Port Elizabeth (3325): Uitenhage Division, Aloes [railway siding, portion of Wells Estate] (-DC), elev. ca. 154 feet, 17 April 1912 (in flower), I.L. Drège 3122 (GRA!); Port Elizabeth (3325): Redhouse (-DC), October 1911 (in flower), T.V. Paterson 2175 (GRA!); Port Elizabeth (3325): Redhouse (-DC), November 1914 (in flower and fruit), T.V. Paterson 2175 (GRA!); Port Elizabeth (3325): Redhouse, near Hockey field (-DC), clay, valley bushveld disturbed, 2 November 1991, N.R. Urton 1108 (GRA!).

\section{Acknowledgements}

This work was partly supported by H2020 Research and Innovation Staff Exchange Programme of the European Commission, project 645636: 'Insect-plant relationships: insights into biodiversity and new applications' (FlyHigh), and the grants ACIE18-03 UAUSTI18-02 from the University of Alicante. We thank the curators of the herbaria who provided access to the specimens examined. We gratefully acknowledge Charles Marais for his kindness and enthusiasm in documenting the flora of Huguenot Farm. 


\section{References}

Dold, A.P. \& Brink, E. (2004) Drimia chalumnensis (Hyacinthaceae-Urgineoideae), a new species from Eastern Cape, South Africa. South African Journal of Botany 70: 631-634. https://doi.org/10.1016/S0254-6299(15)30202-7

Glen, H.F. \& Germishuizen, G. (2010) Botanical exploration of southern Africa, ed. 2. Strelitzia 26. South African National Botanical Institute, Pretoria, 489 pp.

IPNI (2019+) The international plant names index. Available from: http://www.ipni.org (continuously updated, accessed January 2019)

Jacquin, N.J. (1797) Observationes botanicae DXIX-DCLXXI. Collectaneorum Supplementum 5. Officina Wappleriana, Vindobonae [Wien], $220 \mathrm{pp}$.

Leistner, O.A. \& Morris, J.W. (1976) Southern African place names. Annals of the Cape Provincial Museum 12: 1-565.

Manning, J.C. \& Goldblatt, P. (2018) Systematics of Drimia Jacq. (Hyacinthaceae: Urgineoideae) in southern Africa. South African National Biodiversity Institute, Pretoria, $173 \mathrm{pp}$.

Martínez-Azorín, M., Crespo, M.B. \& Juan, A. (2007) Taxonomic revision of Ornithogalum subg. Cathissa (Salisb.) Baker (Hyacinthaceae). Anales del Jardin Botánico de Madrid 64: 7-25.

Martínez-Azorín, M., Crespo, M.B. \& Juan, A. (2009) Taxonomic revision of Ornithogalum subg. Beryllis (Hyacinthaceae) in the Iberian Peninsula and the Balearic Islands. Belgian Journal of Botany 142: 140-162.

Martínez-Azorín, M., Crespo, M.B., Alonso-Vargas, M.A., Dold, A.P., Pinter, M. \& Wetschnig, W. (2018a) Austronea (Asparagaceae, Scilloideae), a new genus from southern Africa, including the description of seven new species. Phytotaxa 365 (2): $101-129$. https://doi.org/10.11646/phytotaxa.365.2.1

Martínez-Azorín, M. Crespo, M.B., Pinter, M., Slade, J.M. \& Wetschnig, W. (2018b) losanthus (Hyacinthaceae subfam. Urgineoideae), a new genus from southern Africa to include Ornithogalum toxicarium and its removal from Ornithogaloideae. Plant Biosystems. [published online] https://doi.org/10.1080/11263504.2018.1527793

Mucina, L. \& Rutherford, M.C. (Eds.) (2006) The vegetation of South Africa, Lesotho and Swaziland. South African National Biodiversity Institute, Pretoria, $807 \mathrm{pp}$.

Rafinesque, C.S. (1837) Flora Telluriana 3. H. Probasco, Philadelphia, PA, 100 pp.

Schonland, S. (1919) Botanical survey of South Africa, Memoir N 1 , Phanerogamic flora of the divisions of Uitenhage and Port Elizabeth. Government Printing and Stationery Office, Pretoria, $118 \mathrm{pp}$.

Schlechter, F.R.R. (1897) Decades plantarum novarum austro-africanarum. Journal of botany: British and Foreign 35: 428-433.

Steinheil, A. (1834) Note sur le genre Urginea nouvellement formé dans la famille des Liliacées. Annales des Sciences Naturelles, Botanique, Sér. 2, 1: 321-332.

Thiers, B. (2019+) Index Herbariorum: A global directory of public herbaria and associated staff. New York Botanical Garden's Virtual Herbarium. Available from: http://sweetgum.nybg.org/ih/ (continuously updated; accessed January 2019)

Vanderplank, H.J. (1998) Wildflowers of the Port Elizabeth Area: Swartkops to Sundays Rivers. Bluecliff Publishing, Hunters Retreat, $160 \mathrm{pp}$.

Willdenow, C.L. (1799) Caroli a Linné Species Plantarum. Editio Quarta, vol. 2 (1). Impensis G.C. Nauk, Berolini [Berlin], 823 pp. 